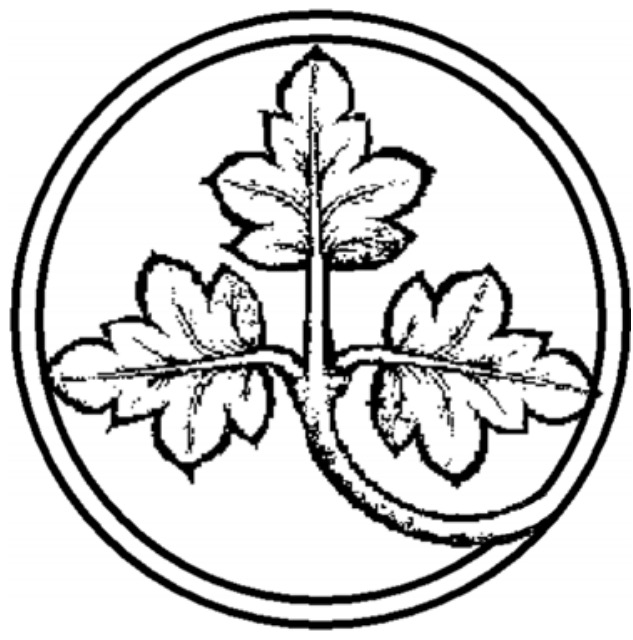

\author{
Preprints of the \\ Max Planck Institute \\ for Research on Collective Goods \\ Bonn \\ 2003/8
}

The Democratic Legitimacy of Business Interest

Representation in the European Union:

Normative Implications of the Logic of Access

Pieter Bouwen 


\title{
The Democratic Legitimacy of Business \\ Interest Representation in the European Union: Normative Implications of the Logic of Access
}

\author{
by \\ Pieter Bouwen \\ bouwen@mpp-rdg.mpg.de
}

\begin{abstract}
This paper studies the capacity of business interests to contribute to the democratic legitimacy of EU governance through participation in the EU policy-making process. Whereas the unbalanced participation of business as opposed to non-business interests in EU policy-making has been problematized, no research has been conducted regarding the unequal participation of different organizational forms of business interest representation (companies, associations and consultants). Here, first it is argued on the basis of a theory of access that this unequal participation has important repercussions because the different organizational forms do not have the same potential to contribute to the legitimacy of EU governance. The theoretical approach makes it possible to bridge the gap between the EU legitimacy debate and the literature on EU business interest representation by establishing a relationship between the new concept of 'access goods' and the existing notions of input/output legitimacy. Second, an empirical investigation of business interest participation is undertaken in order to systematically assess the empirical relevance of the normative propositions and consequently to make inferences about the democratic legitimacy of business interest participation in the EU policy-making process.
\end{abstract}




\section{Introduction ${ }^{1}$}

There is agreement in the field of European interest politics that business interests are much better represented in Brussels than other societal interests (Mazey and Richardson, 1999:121). The majority of the national and European interest groups and consultants in Brussels represent producer interests (Buholzer, 1998:13; Greenwood, 1997:101, Schmitter, 2000). This paper starts from the observation that whereas there have been numerous studies contrasting the participation of business interests in European public policy with the participation of diffuse and/or non business interests (Pollack, 1997), no research has been undertaken comparing the access of different forms of business interest representation to the EU institutions. Indeed, while the unequal participation of business interests as opposed to consumer groups, environmental groups and human right groups, etc. has been extensively analyzed, the access of different organizational forms of business interest representation to the EU policy-making process remains understudied. Table 1 below presents the main organizational forms that lobbying activities can take in the European Union: national and European business associations, individual company action and political consultants (Bouwen, 2002:373). ${ }^{2}$

Table 1: Main Organizational Forms of Business Interest Representation

\begin{tabular}{lccc}
\hline & Individual action & Collective action & Third party \\
\hline National level & Indiv. Nat. Action & National association & National consultant \\
European level & Indiv. EU action & European association & Brussels consultant \\
\hline
\end{tabular}

In this paper, I argue that the differences in the degree of access that these organizational forms have is likely to have significant repercussions on the legitimacy of EU governance, just as the biased access favoring business interest, as opposed to non-business interests, might threaten the legitimacy of the EU decision-making process. On the basis of a theory of access, it is argued that individual companies, business associations and consultants do not all have the same potential to contribute to the legitimacy of EU governance (Bouwen, 2001). The aim of this paper is to assess the democratic legitimacy of the participation of these different organizational forms of business interest representation in the EU decision-making system. However, it needs to be em-

1 I am grateful to Dirk De Bièvre, Christoph Engel and Leonor Moral Soriano of the Max Planck Institute for Research on Collective Goods in Bonn for their detailed comments on earlier versions of this paper. In particular, I would like to thank Dieter Kerwer for the numerous interesting discussions in Bonn. In addition, I would like to thank Kenneth Armstrong, Peter Bonnor, Tom Burns, Deirdre Curtin, Renaud Dehousse, Olivier De Schutter, Roland Erne, Robert Geyer, Carol Harlow, Hubert Heinelt, Paul Magnette, Carlo Ruzza, Sabine Saurugger and in particular Stijn Smismans for their interesting remarks during the Workshop on "European Governance and Civil Society” in May 2003 at the Fondation Nationale des Sciences Politiques in Paris. Finally, I am grateful to Darrell Arnold for the language corrections.

2 Apart from these traditional organizational forms, important new collective fora have been established during the last decade to collectively represent and promote business interests. The most remarkable development in the area of business interest representation has been the rapid growth of collective fora allowing for the direct participation of firms (Bouwen, 2002:373). Even though the reasoning elaborated in this paper could also be applied to these new collective fora, the analysis is limited to the main organizational forms. 
phasized that this theoretical and empirical inquiry into the legitimacy of EU business interest representation does not mean to divert attention from the problematic overrepresentation of business interests in the EU multi-level system.

Legitimacy has become a major issue for the European institutions since the Single European Act and the Treaty of the European Union. ${ }^{3}$ These major treaty revisions led to a significant transfer of political decisions and allocations from the national to the European level. Some authors have argued that this new institutional infrastructure has substantially weakened democratic influence and control at the national level, and that there has been a failure to compensate for this by establishing equally strong democratic institutions and processes at the European level (Christiansen, 1997; Höreth, 1999; Bellamy and Castiglione, 2000). They claim the European institutions suffer from a 'democratic deficit' and propose institutional reforms in order to increase the legitimacy of European governance. ${ }^{4}$ Others, however, find little evidence that the EU suffers from a fundamental democratic deficit (Mény, 2002; Moravscik, 2002; Crombez, 2003). ${ }^{5}$ Notwithstanding fundamental disagreement in the literature, the current debate on the democratic caliber of European governance legitimizes the focus taken up in this article on the contribution that different forms of business interest representation can make to the legitimacy of the EU decision-making process.

For a long time, the academic and political debate on Europe's democratic deficit has focused on the issue of territorial representation (Smismans, forthcoming (a)). It follows that the parliamentary model has been used as a framework for defending the steady increase in the European Parliament's competencies and its control over the European Commission (Dehousse, 1998:601; Lodge, 1996:193). The issue of functional representation has remained surprisingly absent in the debate. In contrast with the European Parliament, which is composed of territorial representatives, the Economic and Social Committee (ESC) can be regarded as a functional assembly (Smismans, 2000:6). The ESC brings together "representatives of the various economic and social components of organized civil society". ${ }^{6}$ More concretely, the ESC is composed of representatives of the various categories of economic and social activity such as representatives of producers, farmers, carriers, workers, dealers, craftsmen, professional occupations and the general public. While the ESC embodies a forum for functional representation within the EU institutional framework, the well-developed and widespread lobbying practices and multiple forms of interest group participation at the European level provide an alternative channel for the representation of functionally defined interests vis-à-vis the EU institutions.

\footnotetext{
3 For a definition of the concept of legitimacy and its implication take a look at Schmitter (2001).

4 David Marquand originally coined the famous phrase "democratic deficit" in an analysis of the functioning of the European Community Institutions in order to underline the weakness of their democratic components (Marquand, 1979).

5 They mostly judge the democratic character of the EU institutional setting in reference to the practices of existing nation-states and the context of a multi-level system.

6 This is the definition in the revised version of Article 257 of the EC Treaty since the ratification of the Treaty of Nice.
} 
Only recently, certain authors have come to view the participation of interest groups in the European policy-making process as an additional source of legitimacy for the European polity (Andersen and Burn, 1996; Wessels, 1999; Smismans, forthcoming (a)). An important reason for this is that the field of European interest politics that studies the functional representation of private interests in EU policy-making has not mainly dealt with the legitimacy of European governance, but with other issues. This literature has focused much more on characterizing the overall system of interest representation, i.e. on determining whether it should be characterized in terms of pluralism or corporatism, and on depicting the different channels used by interest groups to influence the EU institutions (Streeck and Schmitter, 1991; Bennett, 1997; Kohler-Koch and Quittkat 1999; Bouwen 2002). ${ }^{7}$ However, there is disagreement about the extent to which functional representation can contribute to the democratic legitimacy of European governance. Whereas some authors regard it as substituting for the traditional basis of democratic legitimation, i.e. the parliamentary model (Héritier, 1999), others tend to view it more as a source of complementary legitimacy (Lord and Beetham, 2001).

Also the EU institutions themselves, in particular the European Commission and the Economic and Social Committee, have taken up the issue of functional representation. Referring to their interactions with numerous interest groups and intermediary organizations, both European institutions have developed a legitimating discourse around the concepts of 'civil society' and 'civil dialogue' (Smismans, forthcoming (b)). ${ }^{8}$ They argue that functional representation through the systematic involvement of civil society organizations in European policy-making may constitute a form of participatory democracy, complementing traditional representative democracy. Civil society is considered to play an important role in giving voice to the concerns of citizens and delivering the services that meet people's needs. The organizations that make up civil society mobilize people and support.

Apart from trade unions, non-governmental organizations, professional associations and grassroots organizations, the Commission and the ESC also consider business interest representation (e.g. employers' organizations or sectoral business associations) to be an important part of

7 On the margin, this literature has pointed to the overrepresentation of business interests in Brussels and the difficulties diffuse interests have becoming established at the European level.

8 Initiatives of the EUROPEAN COMMISSION: Communication on "Promoting the role of voluntary organizations and foundations in Europe", Brussels, 06.06.1997, COM (97) 241 final. Communication on "The Commission and non-governmental organizations: building a stronger relationship", Brussels, 18.01.2000, COM (2000) 11 final. Communication on "European Governance: A White Paper", Brussels 25.7.2001, COM (2001) 428 final. Communication "Consultation document: Towards a reinforced culture of consultation and dialogue - Proposal for general principles and minimum standards for consultation of interested parties", Brussels, 05.06.2002, COM (2002) 277 final. Communication: "Towards a reinforced culture of consultation and dialogue - General Principles and minimum standards for consultation of interested parties by the Commission", Brussels, 11.12. 2002, COM (2002) 704 final.

Initiatives of the ECONOMIC AND SOCIAL COMMITTEE: Opinion on "The role and contribution of civil society organizations in the building of Europe", Brussels 22.09.1999. Opinion on "The 2000 Intergovernmental Conference - The Role of the European Economic and Social Committee", Brussels, 01.03.2000. Opinion on "Organized civil society and European governance: the Committee's contribution for the White Paper", Brussels, 26. 04.2001. 
Europe's civil society. ${ }^{9}$ This is clearly in contrast with a specific strand in the literature on European civil society that considers only those groups as civil society organizations that are non profit organizations and serve the general interest. This literature rests on the assumption that a clear distinction can be made between a political society composed of parties and political organizations, an economic society composed of organizations of production and distribution and a civil society composed associations, social movements and other forms of political communication (Cohen and Arato, 1997). In the real world, however, the borders between civil society, state and market might not always be easy to draw. Business interest associations, for example, neither have the specific characteristics of market actors nor are they focused on serving the interest of the general public. It seems therefore plausible for EU policy-makers to include different organizational forms of business interest representation in their list of civil society organizations.

It is the aim of this paper to study the legitimating role that different organizational forms of business interest representation might play by participating in the EU policy-making system. In the next section, a new theoretical framework for studying European business lobbying, the 'logic of access', is discussed, and the implications of the framework for the legitimacy of EU governance are investigated. After these theoretical considerations, section three presents an extensive empirical investigation of the interaction between business interests and the EU institutions in the EU financial services area in order to make inferences about the significance of this interaction for the democratic legitimacy of the EU policy-making process. In the fourth section, the impact of the empirical study for the overall legitimacy of the three main EU institutions is studied.

\section{Normative Implications of the Logic of Access}

It is the aim in this section to establish a link between the field of European interest politics and the debate on the legitimacy of the European Union. The starting point is the presentation of a new theoretical framework for the study of business lobbying in the European Union. In this framework, the concept of 'access goods' plays a central role. Afterwards, this concept is used to establish the relationship with the EU legitimacy debate.

\subsection{A Theoretical Framework to Study Corporate Lobbying}

The logic of access provides a new theoretical framework for the study of business lobbying in the European Union. The framework seeks to improve our understanding of how business interests gain access to the EU institutions and influence the making of legislation at the European

9 See the Commission's White Paper on European Governance p. 14 and the ESC Opinion on "The role and contribution of civil society organizations in the building of Europe", p. 30. For a definition of European civil society, take a look at Smismans (forthcoming (b)). 
level. ${ }^{10}$ More specifically, the logic of access has been developed in order to explain the access of different organizational forms of business interest representation to the three major players in the EU legislative process, i.e. the European Commission, the European Parliament and the Council of Ministers (Bouwen, 2002 and forthcoming (b)). The degree of access to these institutions is explained in terms of a theory of the supply and demand of access goods. Whereas business interests are responsible for the provision of access goods, the EU institutions want certain goods from business interests in return for 'access' to the EU agenda-setting and policy-making process. In short, in order to gain access to a specific EU institution, business interests have to provide the access good(s) demanded by that institution.

Access goods concern information that is crucial in the EU policy-making process (Bouwen, 2002:369). Because the new concept of 'access goods' is crucial in this paper for the link between business lobbying and the EU legitimacy debate, that concept is studied in detail in the following paragraphs. Three access goods can be identified. They concern three different kinds of information, and can be specified as follows:

1. Expert Knowledge (EK): This access good concerns the expertise and technical know-how needed from the private sector to understand the market. This kind of information is indispensable for the development of effective EU legislation in a particular policy area. Example: The technical expertise provided by Barclays Bank to help EU officials and politicians to understand the particularities of the capital adequacy rules for commercial banks.

2. Information about the European Encompassing Interest (IEEI): This access good concerns the information needed from the private sector about the European encompassing interest (EEI). In our sectoral approach, the EEI concerns the needs and interests of a sector in the European economic arena, i.e. the internal market. ${ }^{11}$ Example: The information provided by the European Banking Federation about the needs and interests of its members with regard to new capital adequacy rules for commercial banks.

3. Information about the Domestic Encompassing Interest (IDEI): This access good concerns the information needed from the private sector about the domestic encompassing interest (DEI). In our sectoral approach, the DEI concerns the needs and interests of a sector in the domestic market. Example: The information provided by the Belgian Bankers Association about the needs and interests of its members with regard to new capital adequacy rules for commercial banks.

The importance of expert knowledge in the EU decision-making process has been widely acknowledged in the literature (Bowen, 1997; Buholzer, 1998, Pappi et al., 1999; Van Schendelen,

10 It should be emphasized that access does not necessarily mean influence. Ineffective political actors might gain access to an institution without being able to translate this advantage into concrete policy outcomes. Gaining access is, however, a conditio sine qua non to the exercise of influence in the EU legislative process. 
1994). ${ }^{12}$ The European Commission, for example, does often not have this kind of technical market expertise. Even though the Commission does have a lot of technical know-how at its disposal, it is too distant from the market to be well informed.

The two 'encompassing access goods' have not been previously identified. ${ }^{13}$ It is therefore necessary to study the meaning of the concept, 'encompassing interest', in more detail. An interest is more encompassing when more interested parties are involved in the formulation of the interest. An aggregation of individual interests or interested parties takes place. The involved parties can be individual companies or associations. A national trade association can, for example, be said to represent an encompassing interest because it is specialized in bundling the needs and interests of its member companies. Since the aggregation of interests takes place at the national sectoral level, the domestic encompassing interest is concerned. For the European encompassing interest, interests are aggregated at the European sectoral level. Two variables determine the 'encompassingness' of an interest represented by an interest group (Schmitter and Streeck, 1999:58). First, the demarcation of the interest group's organizational domain is important. It determines the variety of interests and thus the kind of members the association wants to represent. Second, the representativity of the interest group plays a crucial role (Buholzer, 1998:55; Salisbury, 1979:222). It is based on the density of the interest group's membership and is the basis upon which the interest group is recognized as a legitimate interlocutor by the public authorities. This detailed discussion of the different access goods is now used to study their implications for the legitimacy of the EU policy-making process.

\subsection{Identifying the Relationship between Access Goods and Legitimacy}

Before engaging in the discussion of the democratic legitimacy of EU governance, it is important to first make a distinction between 'input' and 'output' legitimacy (Scharpf, 1999:6). Input legitimacy concerns democratic decision-making at the European level. In accord with the demands of input legitimacy, the democratization of the European governance system should take place by involving citizens and interested groups as much as possible in the decision-making and monitoring processes. Output legitimacy concerns the EU's general effectiveness in dealing with problems and generating policy outputs. As long as European policy-making is effective enough to lead to more benefits than costs, the support of large parts of the European population is unlikely to be questioned. Indeed, improved policy outputs engender an increased social acceptance or the increased legitimacy of the policy-making process. This is a technocratic or utilitarian source of legitimacy.

12 Also Franz Pappi (1999:258) identifies expert knowledge as a crucial resource demanded by the EU governmental actors in exchange for the control of policy decisions and the monitoring of information.

13 René Buholzer (1998:54) identifies legitimacy as an important exchange good (Tauschgut). An interest group should be representative enough to be recognized by the public actors as a legitimate interlocutor. As discussed in this paper, the notions of legitimacy and encompassingness are closely related. It is therefore not surprising that Buholzer's Tauschgut, legitimacy, and the two encompassing access goods have similar characteristics. Also Franz Pappi's (1999:257) notion of public support as exchange resource can easily be related to the two encompassing access goods. 
Scharpf's distinction between input and output legitimacy is based on the input-output dichotomy in David Easton's political system theory (1965:112 and 1967:32). In accordance with Easton's ideas, Scharpf distinguishes a source of legitimacy both at the input and the output side of the EU policy-making process (Scharpf, 1999:6). He views the European Union as a political system and consequently applies the notions of input and output legitimacy at the systemic level. It is important to emphasize that, in contrast with Scharpf, in this paper the notions of input and output legitimacy are applied at the sub-systemic or meso-level. Indeed, the theoretical framework and empirical study are situated at the sectoral or meso-level and it is at this level that the two notions of legitimacy are applied. ${ }^{14}$ This clarification is conceptually very important. Whereas business interest representation is mainly viewed as a source of output legitimacy at the systemic level, it is argued in this paper that at the sectoral or meso-level a distinction can be made between business representation as a source of both input and output legitimacy. ${ }^{15}$ This is further clarified in the following paragraphs.

In order to bridge the gap between the EU legitimacy debate and the literature on EU business interest representation, it is argued that a relationship can be identified between specific access goods, on the one hand, and input/output legitimacy, on the other hand. Input legitimacy is directly related to the two encompassing access goods, i.e. information about the European encompassing interest and information about the domestic encompassing interest. These access goods provide input legitimacy to the EU institutions because they serve as a source of information about encompassing and representative interests. Different interested parties have participated in articulating these interests, and the transfer of this information by the business interest representatives allows the interested parties to participate indirectly in the EU policy-making process. ${ }^{16}$ Output legitimacy is, on the other hand, closely linked with the access good, expert knowledge. This access good provides the EU institutions with the necessary expertise to deal with their problems efficiently. It increases the EU's general effectiveness and thereby increases the EU institutions' output legitimacy. Furthermore, output legitimacy is also related to the two Encompassing access goods. The more encompassing the access goods provided by interest groups are, the more likely these interests groups can contribute to the implementation of EU legislation and consequently to effective generation of policy outputs (Bouwen, 2002:371). Why is this? In order to provide an encompassing access good, different individual interests have to be aggregated within the interest group. This means that more encompassing access goods are

14 A parallel can be drawn to the well-known distinction between corporatism and meso-corporatism in the industrial relations literature. Whereas the concept of corporatism refers to a situation at the systemic level, meso-corporatism focuses on a phenomenon at the sectoral level (Schmitter, 1979; Cawson, 1985).

15 Along the same lines, also Smismans considers the functional participation in the Advisory Committee for Safety, Hygiene and Health Protection at Work as a way to increase both input and output legitimacy (Smismans, forthcoming (a)).

16 The different parties who participate in the articulation of the common or encompassing interest often have a different degree of influence over the final common position. Some parties are more resourceful than others and can therefore exercise more influence in the negotiation and deliberation process. 
provided by interest groups, which can aggregate more individual interests, thereby enhancing these groups' potential to contribute to the implementation of EU legislation. ${ }^{17}$

Because of the relationship that has been identified between access goods and legitimacy, the capacity business interest representatives enjoy to provide these goods to the EU institutions determines the degree (more or less) and the kind of legitimacy (input/output legitimacy) these interest representatives can provide. Therefore a systematic investigation of the capacity of business interests to supply the different access goods is indispensable. According to the logic of access, different organizational forms of business interest representation enable the provision of different access goods (Bouwen, 2002:372). Four main organizational forms of business interest representation can be distinguished in the EU: national and European associations, individual companies and political consultants. The following paragraphs investigate the capacities of these organizational forms to provide access goods.

The resource asymmetry between large and small firms explains the superior capacity of large firms to provide access goods. In comparison with associations or consultants, large firms are directly active in the market and they are therefore particularly good at providing expert knowledge. The strategies of large firms can be national or European. The capacity of an individual firm with a domestic strategy to provide information about the domestic encompassing interest remains low. The encompassingness of its interest is limited because only a single domestic firm is concerned. For the same reasons, large individual firms with a European strategy cannot claim to provide information about the European encompassing interests.

Associations are not as good as individual firms at providing expert knowledge because they have fewer resources and they have to deal with a wider range of issues. It has become something of an orthodoxy throughout the EU institutions that trade association officials are "industrial civil servants" who lack the expertise needed to inform policy formulation (Greenwood and Webster, 2000:5). Because of their multi-layered organizational structure, associations are too distant from the market reality. European associations are specialized in building consensus positions by channeling the different opinions of their member associations. They aggregate the interests of their member associations, which, for their part, are already the result of a bundling of the needs and interests of these national associations' member companies. This extensive consultation mechanism allows the European associations to present an encompassing European perspective on their sector and thereby to provide good quality information about the European encompassing interest. Similar reasoning can be applied to national associations. They represent the national sectoral interest and can therefore provide high-quality information about the do-

17 Two additional variables co-determine the extent to which private interest groups can contribute to compliance with EU rules. The first variable is the capacity of interest groups to control their members. Not in all interest groups do the organizational structures and decision-making mechanisms allow a high degree of control over membership (Greenwood and Webster, 2000:2). The second variable is the relationship between private interest groups and public authorities. A close, co-operative relationship can be the basis for a neocorporatist arrangement of private interest government, whereby private interests are made co-responsible for the implementation of legislation in an effort to reduce the authorities' implementation costs (Streeck and Schmitter, 1985). 
mestic encompassing interest. Like other associations, national associations tend not to be very good at providing expert knowledge.

In contrast with individual companies and associations, consultants have a very limited capacity to provide access goods. Because consultants do not represent their own interests, they cannot provide the two encompassing access goods. Moreover, they can only provide expert knowledge when they are specialized in a particular policy area. In Brussels, specialized consultants are an exception, however.

The preceding analysis allows us to derive a number of normative implications of the logic of access. While a clear relationship has been established between access goods, on the one hand, and input/output legitimacy, on the other, the investigation has also shown that the different access goods are provided by different organizational forms of business interest representation. ${ }^{18}$ Based on these two findings, it is possible to derive the extent to which the different organizational forms can contribute to the input or output legitimacy of the EU institutions with which they interact. Whereas the capacity of individual companies, and to a much lesser extent of consultants, to provide expert knowledge enables them to contribute only to the output legitimacy of the EU institutions, the specialization of national and European associations in providing Encompassing access goods guarantees that they will be able to contribute to both the input and output legitimacy of the EU policy-making process. A systematic overview of the business interests' supply of access goods and their consequential capacity to contribute to the input or output legitimacy of the EU institutions is presented in Table 2 below.

Table 2: Relationship between Access Goods and Legitimacy

\begin{tabular}{|l|c|c|}
\hline & Access Good & Legitimacy \\
\hline Individual Firm & EK & Output Legitimacy \\
\hline European Firm & IEEI & Input and Output Legitimacy \\
\hline National Association & IDEI & Input and Output Legitimacy \\
\hline Consultant Association & (EK) & (Output Legitimacy) \\
\hline
\end{tabular}

18 At most, organizational forms can provide, at least to some extent, each of the three access goods. When they succeed in this, it is possible to develop a ranking of the organizational forms' capacity to provide the different access goods (Bouwen, 2002:378). In order to streamline the argument we only focus here on the access goods that can be best provided by the different organizational forms. 


\section{Normative Judgements based on Empirical Evidence}

\subsection{The Need for Empirical Research on the EU's Democratic Deficit}

In the previous section, it was clearly shown that, through the provision of access goods, the interaction of the different organizational forms of business interest representation with the EU institutions has a direct impact on the legitimacy of these institutions. In order to assess the extent to which business interests can contribute to the democratic legitimacy of single EU institutions and of the EU policy-making system in general, it is indispensable that the level of participation or the degree of access that different organizational forms enjoy to the EU institutions be studied. Indeed, a specific organizational form will only be able to contribute to the legitimacy of an EU institution when the organizational form enjoys effective access to the institution. It can be concluded that a systematic empirical analysis of the participation of the different forms of business interest representation in the EU policy-making process would constitute a solid basis for a judgment about the democratic legitimacy of the participation of business interests in the EU policy-making system.

In this section, an empirical study is undertaken, which aims to address a bias in the existing literature on the EU's democratic deficit. This literature is characterized by a misplaced separation between normative reflection on political values and the empirical analysis of political systems (Lord, 2001). An important negative consequence is the methodological underdevelopment of the area of inquiry concerned with the EU's democratic legitimacy. Normative analyses of the democratic deficit are incomplete if they fail to include an empirical assessment of the institutional and societal possibilities for realizing norms or values. Furthermore, when empirical evidence is taken into account in these studies, it mostly concerns anecdotal or ad hoc evidence. In order to remedy this situation, an extensive empirical study has been undertaken in the EU financial services sector. Its aim has been to systematically map out the participation of different organizational forms of business interests representation in the EU decision-making process. Access of business interests to the relevant institutions in the policy-making cycle, i.e. Commission, Parliament and Council, is taken as an indicator of the participation of these interests in the decision-making process.

The EU financial services sector has been chosen in order to allow an empirical check of the access of business interests. Over the last decade, Europe's political leaders have focused their attention on the construction of the Economic and Monetary Union, but they failed to develop the regulatory infrastructure required for the integration of the Member States' financial services markets (Zavvos, 1994:27-32; Dyson and Featherstone, 1999). Since the success of the single currency cannot be guaranteed without well-functioning financial markets, the European Commission devised the Financial Services Action Plan in 1998 in order to inject new momentum into the task of building a single financial market (Mogg, 1999:11). ${ }^{19}$ The numerous legislative

19 Commission communication on "Financial Services: Building a Framework for Action”, Brussels, 28.10.98, COM (1998) 625. In June 1998, the Cardiff European Council requested that the European Commission table an action plan to improve the single market in financial services. 
measures proposed by the European Commission since 1998 have had important distributive effects on the financial services providers, and, through lobbying and public consultation, they have consequently generated intense interactions between these private interests and the EU public authorities. Given the increased participation of financial services providers in the EU policy-making process over the past few years, this has become a particularly interesting policy area for the study of the potential contribution of these business interests to the democratic legitimacy of EU policy-making in this sector.

\subsection{Mapping the Participation of Business Interests in EU Decision-Making}

In order to map the participation of business interests in the EU decision-making process, it is necessary to systematically investigate the access that the different organizational forms of business interest representation have to the European Commission, the European Parliament and the Council of Ministers. However, both the EU institutions and the business interests may have interesting information about access. Since we are interested in relative access, in gathering data here it has been necessary to focus on the EU institutions. The latter are approached by the different organizational forms in order to gain access and they are therefore in the best position to evaluate the relative access granted to business interests. Business interests are mostly unaware of the access enjoyed by other private interests, and it is therefore extremely difficult for them to correctly assess the relative access they have to the EU institutions. Rather than studying business interests directly, the entire empirical investigation is therefore based on 63 semi-structured interviews with EU officials and politicians belonging to the three EU institutions. ${ }^{20}$

A set of structured questions was developed in order obtain comparable and quantifiable data about the access of the four organizational forms of business interest representation. Whereas structured questions were inserted in the semi-structured interviews to obtain quantifiable data, at the same time open questions made it possible to generate more qualitative in-depth knowledge (King, 1995). Both the quantitative and qualitative data from the semi-structured interviews have been used to assess the access of the organizational forms to the EU institutions. The interval scale measurement of the degree of access is calculated on the basis of the method of paired comparison (Guilford, 1954; Swannborn, 1993). This is a one-dimensional scaling method that allows ordinal scale values to be converted into interval scale values. The ordinal scale values were collected in the semi-structured interviews in which all the interviewees had to rank the degree of their contact with the previously mentioned four organizational forms of business interest representation. The interviewees, i.e. officials and politicians, had to indicate which of the four organizational forms they have had contact with, taking the usefulness and the regularity of the contacts into account. The resultant rankings indicate which organizational forms the interviewees have chosen as their first, second, third and fourth choice. After converting the

Commission communication on "Financial Services - Implementing the Framework for Financial Markets: Action Plan”, Brussels, 11.05.99, COM (1999) 232.

20 Between June 2000 and May 2002 the author conducted 63 semi-structured interviews. The total amount of time spent on interviewing officials and politicians in the three institutions was 54 hours and 25 minutes. 
ordinal scale values into interval scale values, these latter were used to calculate the relative access values of the four organizational forms. In the next section, the relative access values are taken as an indicator of the participation of business interests in the EU decision-making process. $^{21}$

\subsection{Empirical Results: Unequal Participation of Business Interests}

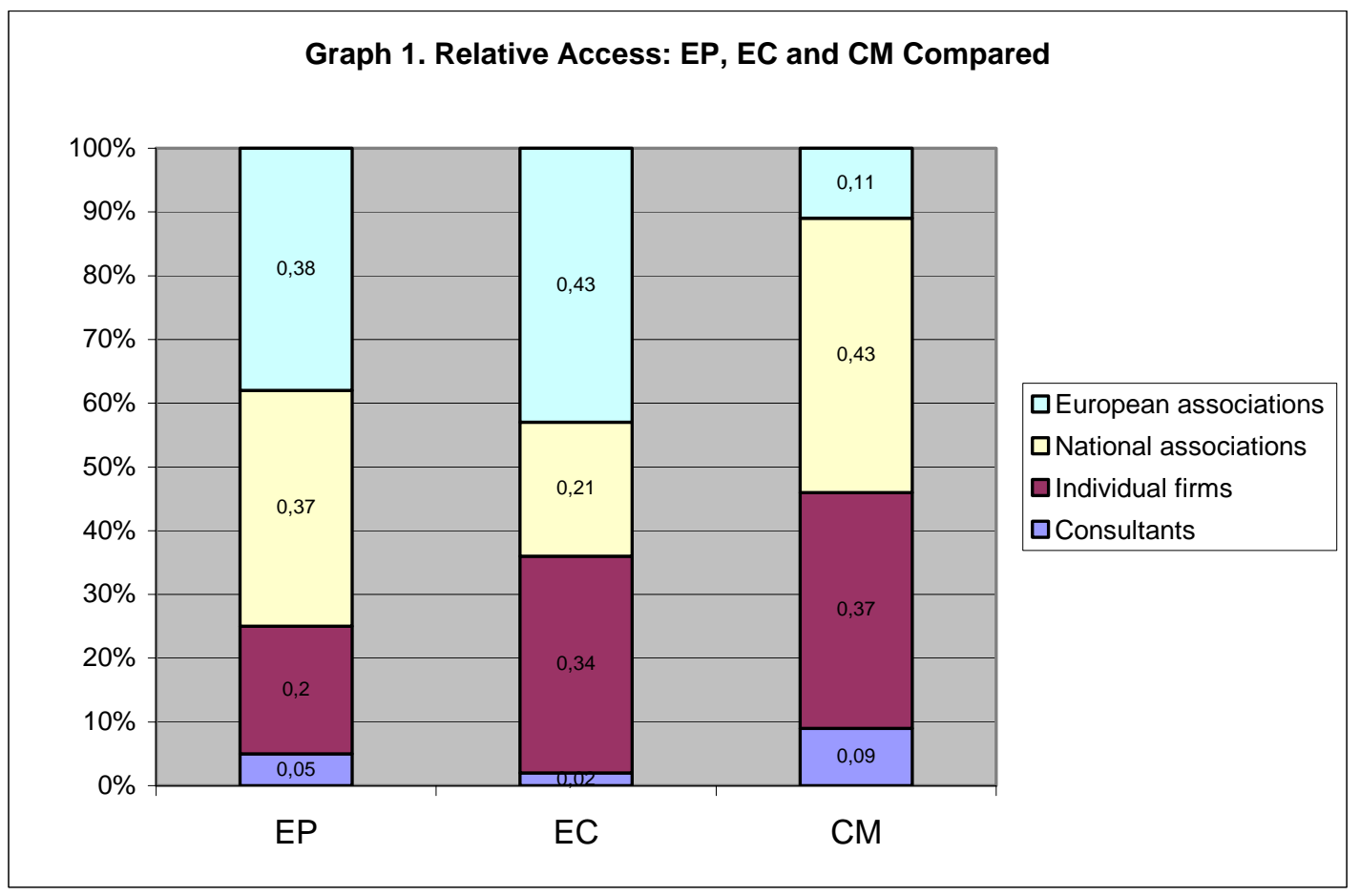

Source: Bouwen, forthcoming (b) $(\mathrm{N}=63)^{22}$

The percentages that result from the calculation of the relative access values are reported in Graph 1. From a comparative inter-institutional perspective, individual firms have a higher degree of access to the European Commission (34\%) and the Council (37\%) than to the European Parliament (20\%). Clearly national associations have a proportionally higher degree of access to the Council of Ministers (43\%) than to the Parliament (37\%) and the Commission (21\%). In addition, the data in the graph show that European associations have a much higher degree of access to the European Parliament (38\%) and the European Commission (43\%) than to the Council of Ministers (11\%). Finally, consultants have a very low degree of access to the three EU institutions (Parliament $=5 \%$, Commission $=2 \%$ and Council $=9 \%$ ). The results of the empirical investigation show clearly that the different organizational forms have unequal access to the EU institutions. In other words, the different forms participate unequally in the EU decision-making process. This begs the following question: Is the unequal participation of the

21 For a more detailed description of the methodology and the calculations see Bouwen (forthcoming (b)).

22 EP=European Parliament, EC=European Commission, CM=Council of Ministers. 
different organizational forms of business interest representation problematic for the democratic legitimacy of the EU policy-making process? This question is dealt with in the next section.

\subsection{Consequences for the Democratic Legitimacy of EU Policy-Making}

Earlier in this paper, the extent to which different organizational forms can contribute to the input or output legitimacy of the EU institutions was derived. However, a precondition for this contribution is their effective interaction with and access to the EU institutions. Based on the results regarding the relative access of the different organizational forms, it is possible to determine the extent to which the different organizational forms of business interest representation contribute to the input or output legitimacy of the three main EU institutions. More concretely, the higher the degree of access, the more intensive the interaction between the business interests and the EU institutions. This entails a potential stronger contribution to the democratic legitimacy of the concerned institutions. Table 3 below demonstrates the improved input and output legitimacy enjoyed by the EU institutions as a result of the degree of access of the different organizational forms to the EU institutions.

Table 3: Improvement of Legitimacy through Business Participation

\begin{tabular}{|l|c|c|}
\hline & Input Legitimacy & Output Legitimacy \\
\hline European Commission & weak & strong \\
\hline European Parliament & strong & n.a. $^{23}$ \\
\hline Council of Ministers & weak & strong \\
\hline
\end{tabular}

The assessments of improved legitimacy in Table 3 are based on the following reasoning. Whereas a relative degree of access of less than $30 \%$ is considered to be too low in order to results in an improvement of input and/or output legitimacy, a degree of more than $30 \%$ is judged to contribute to a weak contribution to input and/or output legitimacy. A strong improvement is the result of a weak improvement by two different organizational forms. When this reasoning is applied to the European Commission, it follows that the high degree of access that European associations (43\%) and individual companies (34\%) have to the Commission leads to a weak improvement in input legitimacy and a strong improvement in output legitimacy. Both European (38\%) and national associations (37\%) have a high degree of access to the European Parliament. It follows that these two collective forms of business interest representation contribute to a strong improvement in input legitimacy. Theoretically, they could also contribute to a strong improvement in output legitimacy but taking into account the limited role of the Parliament in the implementation of EU legislation and the effective generation of policy outputs, the assessment of improved output legitimacy is considered to be not applicable to the European

23 n.a. = not applicable because the European Parliament is not directly responsible for the implementation of EU legislation and consequently the effective generation of policy outputs. 
Parliament. Finally, the relative high degree of access that European associations (43\%) and individual firms (37\%) have to the Council of Ministers contributes to a weak improvement in input legitimacy and a strong improvement in output legitimacy. It should be pointed out that the consultants' low capacity to provide access goods and therefore to gain access to the EU decision-making process limits their ability to contribute to the improvement in the legitimacy of the EU institutions.

\section{Impact on the Legitimacy of Single EU Institutions}

Having established the potential of the different forms of business interest representation to contribute to the legitimacy of the EU decision-making process, it is now possible to investigate - for each EU institution - the extent to which the interaction with business interests influences the overall legitimacy of the institution.

\subsection{The European Commission}

The Commission is often considered to be the EU institution least reconcilable with traditional democratic theory (Höreth, 1999:254). Although the Commission has many functions comparable to a real government, it is not democratically legitimate in the same way. The Commission has the control over the legislative agenda and thereby enjoys the power to set the priorities for the community as a whole. Since the Maastricht Treaty, the Commission has sought to remedy the democratic deficit and legitimacy problem. An elaborate program of greater openness, transparency and subsidiarity has been the result (Christiansen, 1997:13; Héritier, 1999:271 and forthcoming). The development of a more direct Commission-public relationship was accelerated. Among other things, in an attempt to make the Commission more accountable to the European citizens, the interaction with intermediary social groups and organizations has been encouraged. $^{24}$

In the context of this increasingly closer interaction with civil society, it is argued in this paper that the Commission's systematic and direct interaction with different organizational forms of business interest representation has allowed the supranational institution to increase both its input and output legitimacy. The empirical analysis of access to the Commission has shown that both individual firms and European associations have a very high degree of access. Whereas European associations contribute to a weak improvement in input legitimacy through the provision of encompassing access goods, they contribute together with individual companies to a strong improvement in output legitimacy. Individual companies help to improve the institution's output legitimacy through the provision of expertise. Expert knowledge allows the Commission to deal efficiently and effectively with policy problems (Benz, 2001:6). The Commission's close

24 See footnote 8 for initiatives taken by the European Commission to improve its direct interaction with civil society organizations. 
interaction with European associations and individual companies allows the Commission to tackle its democratic legitimacy problem.

\subsection{The European Parliament}

Like most parliaments at the national level, the European Parliament derives its legitimacy from direct elections organized on the basis of territorial representation. It is the world's only directly elected supranational assembly. The legitimacy issue is therefore less problematic for the Parliament than for the other two EU institutions. This positive normative assessment has been the basis for the Parliament's continuous increase in competencies and responsibilities over the last decade.

One way to further improve the legitimacy record of the European Parliament is to allow functional representation through business interest participation. The study of access to the Parliament confirms that representative organizations, irrespective of the level of interest aggregation (national/European), have a very high degree of access to the Parliament. Parliamentarians seem to give privileged access to interest representatives of European and national associations. These two forms of business interest representation have organizational characteristics, which are beneficial to the provision of encompassing access goods. Consequently, by supplying encompassing access goods, European and national associations together are able to contribute to a strong improvement in the Parliament's input legitimacy. It can be concluded that the intensive contacts of European Parliamentarians with collective forms of business interest representation will improve the already positive legitimacy record of the European Parliament.

\subsection{The Council of Ministers}

The Council of Ministers has always played an important role in legitimizing governance at the European level. The Members of the Council are directly accountable to their national parliaments and electorates. The representatives of the Member States in the Council are national politicians who are elected as politicians at the national level. What this has meant in practice has varied considerably from one Member State to the other. EU policy-making is indeed only a small part of the basis on which the vote at the national level takes place. The Member States and their ministers in the Council remain therefore rather independent from their electorate and nationally organized interests when it comes to European affairs.

However, the Council's capacity to provide 'indirect legitimacy' at the EU level is weakening (Höreth, 1999:254). The steadily increasing competencies of the European Parliament, reached through different treaty revisions, have lead to a decline in the Member State's ability to control European decision-making through the Council of Ministers. For that reason, the state is a declining source of political legitimization in the EU decision-making system. It follows that also for the Council of Ministers the interaction of the Member States with various business interest 
representatives constitutes an alternative source of political legitimization. The results of the empirical analysis show that national associations have a very high degree of access to the Council and contribute to a weak improvement of the Council's input legitimacy by supplying an encompassing access good. In addition, they contribute together with individual firms to a strong improvement of the Council's output legitimacy. This is possible because also these latter enjoy a high degree of access to the Member States. It can be concluded that the interaction of Member State officials with national associations and individual companies provides the Council with an important alternative source of political legitimization by supplying encompassing access goods and expert knowledge.

\section{Conclusion}

The logic of access and the empirical findings that have been presented in this paper provide interesting new input for the normative discussion of Europe's democratic deficit. This new approach made it possible to bridge the gap between the EU legitimacy debate and the literature on EU business interest representation in two important ways. First, by refocusing the EU legitimacy debate from the classical issue of territorial representation on the issue of functional representation. And second, by establishing a relationship between the new concept of 'access goods' and the existing notions of input/output legitimacy. While it has been argued that input legitimacy is directly related to the provision of the two encompassing access goods, it is argued that output legitimacy is linked with both expert knowledge and the encompassing access goods. It has become clear that the capacity of different organizational forms of business interest representation to supply the above-mentioned access goods determines the degree (more or less) and the kind of legitimacy (input/output legitimacy) these business interests can provide to the EU institutions. Whereas the capacity of individual firms to provide expert knowledge allows them only to contribute to output legitimacy, the capacity of national and European associations to provide encompassing access goods enables them to contribute to both the input and output legitimacy of the EU legislative process. ${ }^{25}$

This result clearly shows the different capacity of different organizational forms of business interest representation to contribute to the legitimacy of the EU institutions. Thus, the normative claim of this paper is straightforward: EU institutions should preferably interact with collective forms of business interest representation, i.e. European or national associations, because they can make the most important contribution to the legitimacy of the EU institutions. It is interesting to note that the European Commission itself has openly declared in the past that it prefers to deal with collective forms of interest representation at the European level, i.e. European federations, to individual organizations. ${ }^{26}$ Taking into account the Commission's supranational perspective,

25 When consultants are specialized in a particular policy area, they can also provide expert knowledge and thereby contribute to the output legitimacy of EU policy-making.

26 Commission communication: "An open and structured dialogue between the Commission and special interest groups" (93/C 63/02). 
the European Commission also clearly stated, however, to prefer dealing with associations at the European level rather than with national associations.

Even though ad hoc contacts with individual companies or consultants will remain indispensable for the EU institutions in order to obtain the expert knowledge they require to fulfill their institutional role (Bouwen, 2002:378), they should preferably develop a solid relationship with associational representatives. Only the latter can simultaneously contribute to the input and output legitimacy of the concerned institutions. However, an important caveat needs to be made. Associations are not by definition capable of contributing to the two kinds of legitimacy. 'Fig leave' associations constitute a real problem. They are apparent associations and are often established by a single firm. Their main objective is to conceal the real organizational form of the business interests concerned in order to improve their institutional access. It needs to be emphasized that only associations that can provide the encompassing access goods will be able to contribute to both input and output legitimacy. Two variables play an important role in determining the capacity of the associations to provide encompassing access goods. First the demarcation line of the interest group's is important because it determines the variety of interests and thus the kind of members the associations wants to represent (Schmitter and Streeck, 1999:58). Second, the representativity of the interest group matters and it based on the density of the interest group's membership (Salisbury, 1979:22).

Furthermore, the empirical results of the investigation in the three main EU institutions have shown the unequal participation of different organizational forms of business interest representation in the EU decision-making process and the different effects that entails in terms of input and output legitimacy. The high degree of access of European associations and individual companies to the European Commission leads to a weak improvement of the Commission's input legitimacy and a strong improvement of its output legitimacy. The important degree of access of both European and national associations to the European Parliament contributes to a strong improvement of the supranational assembly's input legitimacy. When comparing the directly elected supranational assembly's solid legitimacy credentials with the legitimacy problems identified within the European Commission, the latter institution is likely to benefit relatively more from intense interaction with business interest organizations. Finally, the results also show that European associations and individual firms contribute to a weak improvement of the Council of Ministers' input legitimacy and a strong improvement of its output legitimacy on the basis of their high degree of access to that intergovernmental EU institution. Through the detailed analysis of the contribution of different organizational forms to the legitimacy of the single EU institutions, this study wants to contribute to the overall investigation of the legitimacy of EU governance.

Finally, the results of this paper might also facilitate an understanding of the inter-institutional conflict that occurred between the European Commission and the European Parliament as a consequence of the publication of the Commission's White Paper on Governance published in 
July 2001 (Bouwen, forthcoming (a)). ${ }^{27}$ Within the framework of the communication, the Commission designed proposals in order to improve the interaction between civil society organizations and the European Commission. The proposals not only constituted commitments and obligations for the European Commission but also for the civil society organizations. Notwithstanding the Commissions' objectives to improve openness, participation and accountability in its interaction with civil society, the European Parliament reacted surprisingly critically to the Commission's reform proposals. The Parliament's negative reaction to the Commission proposals can be understood as an attempt to halt the Commission's bid to reinforce its position in the interinstitutional power struggle at the EU level. A substantially enhanced relationship between civil society and the European Commission would lead to a substantial improvement in the Commission's input and output legitimacy. Without a compensating improvement of the European Parliament's consultation practices with civil society, the Commission proposals therefore constituted a genuine threat to the European Parliament's unique position as the most democratically legitimate EU institution. It can be concluded that there is a fierce competition for consultation between the Commission and the Parliament, which is aimed at safeguarding or improving the position of both institutions in the inter-institutional power struggle.

27 Commission communication on "European Governance, A White Paper", Brussels, 25.0702001, COM(2001) 428 Final. 


\section{References}

Andersen, Svein, and Tom Burns. 1996. The European Union and the Erosion of Parliamentary Democracy: A Study of Post-Parliamentary Governance. in The European Union: How Democratic is it? Editors Svein Andersen, and Kjell Eliassen, 227-51. London: Sage Publications.

Bellamy, R., and D. Castiglione. 2000. The Uses of Democracy: Reflections on the European Democratic Deficit. in Democracy in the European Union. Integration through Deliberation. Editors E. Eriksen, and J. Fossum, 65-84. London: Routledge.

Bennett, R. J. 1997. The Impact of European Economic Integration on Business Associations: the UK Case. West European Politics 20, no. 3: 61-90.

Benz, Arthur. 2001. Restoring Accountability in Multilevel Governance. Paper Presented at the 29th ECPR Joint Sessions of Workshops. Workshop No. 5: "Governance and Democratic Legitimacy", Grenoble/France, 6-11 April 2001: 1-23.

Bouwen, Pieter. 2002. Corporate Lobbying in the European Union: The Logic of Access. Journal of European Public Policy 9, no. 3: 365-90.

. 2001. Corporate Lobbying in the European Union: Towards a Theory of Access. EUI Working Papers SPS No. 2001/5: 47.

. Forthcoming (a). Competing for Consultation: Informal Institutional Change and InterOrganizational Conflict between the European Commission and the European Parliament. in The Battle for Competencies in the European Union. Editors Henry Farrell, Adrienne Héritier and Fredrik Bergstrom.

. Forthcoming (b). Exchanging Access Goods for Access. A Comparative Study of Business Lobbying in the EU Institutions. European Journal of Political Research.

Bowen, Sîan. 1997. Companies, trade associations and information advantage. in Trade associations in Britain and Germany: responding to internationalization and the EU. Editor Robert J. Bennett, 115. York: YPS, York.

Buholzer, René. 1998. Legislatives Lobbying in der Europäischen Union, Ein Konzept für Interessengruppen. Bern-Stuttgart-Wien: Verlag Paul Haupt.

Cawson, Alan. 1985. Organized Interests and the State: Studies in Meso-Corporatism. London: Sage.

Christiansen, Thomas. 1997. Tensions of European governance: politicized bureaucracy and multiple accountability in the European Commission. Journal of European Public Policy 4, no. 1: 73-90. 
Cohen, Jean and Andrew Arato, 1997. Civil Society and Political Theory. Cambridge: MIT Press.

Crombez, Christophe. 2003. The Democratic Deficit in the European Union: Much Ado about Nothing? European Union Politics 4, no. 1: 101-20.

Dehousse, Renaud. 1998. European Institutional Architecture after the Amsterdam Treaty: Parliamentary System or Regulatory Structure? Common Market Law Review 35: 595-627.

Dyson, Kenneth, and Kevin Featherstone. 1999. The Road to Maastricht. Negotiating Economic and Monetary Union. Oxford: Oxford University Press.

Easton, David. 1965. A Framework for Political Analysis. London and Sydney: Prentice-Hall Inc.

1967. A Systems Analysis of Political Life. New York, London, Sydney: John Wiley \& Sons.

Greenwood, Justin. 1997. Representing Interest in the European Union. London: Macmillan Press Ltd.

Greenwood, Justin, and Ruth Webster. 2000. Are EU Business Associations Governable? European Integration Online Papers 4, no. 3: 16.

Guilford, J. P. 1954. Psychometric Methods. New York, Toronto, London: McGraw-Hill Book Company.

Héritier, Adrienne. forthcoming. Composite Democratic Legitimation in Europe: the Role of Transparency and Access to Information. in The Diffusion of Democracy: Emerging Norms and Forms of Democratic Control in the European Union. Editors Olivier Costa, Nicolas Jabko, Christan Lequesne, and Paul Magnette.

- 1999. Elements of democratic legitimation in Europe: an alternative perspective. Journal of European Public Policy 6, no. 2: 269-82.

Höreth, Marcus. 1999. No way out for the beast? The unsolved legitimacy problem of European Governance. Journal of European Public Policy 6, no. 2: 249-68.

King, Nigel. 1995. The Qualitative Research Interview. in Qualitative Methods in Organizational Research. Editors Cassell Catherine, and Symon Gillian. London: Sage Publications.

Kohler-Koch, Beate, and Christine Quittkat. 1999. Intermediation of Interests in the European Union. Arbeitspapiere - Mannheimer Zentrum Für Europäische Sozialforschung, no. 9: 115.

Lodge, Juliet. 1996. The European Parliament. in The European Union: How Democratic is it? Editors Svein S Andersen, and Kjell A. Eliassen, 187-214. London: Sage Publications. 
Lord Christopher. 2001. Assessing Democracy in a Contested Polity. Journal of Common Market Studies 39, no. 4: 641-61.

Lord Christopher, and David Beetham. 2001. Legitimizing the EU: Is there a "Post-parliamentary Basis" for its Legitimation? Journal of Common Market Studies 39, no. 3: 443-62.

Marquand, David. 1979. Parliament for Europe. London: Jonathan Cape.

Mazey, Sonia, and Jeremy Richardson. 1993. Lobbying in the European Community. Oxford: Oxford University Press.

Mény, Yves. 2002. De la démocratie en Europe: Old Concepts and New Challenges. Journal of Common Market Studies 41, no. 1: 1-13.

Mogg, John. 1999. Looking ahead to the next century: EU priorities for financial services. Euredia, European Banking and Financial Law Journal, no. 1: 9-20.

Moravcsik, Andrew. 2002. In Defence of the "Democratic Deficit": Reassessing Legitimacy in the European Union. Journal of Common Market Studies 40, no. 4: 603-24.

Pappi, Franz U., and Christian H. C. A. Henning. 1999. The organization of influence on the EC's common agricultural policy: A network approach. European Journal of Political Research, no. 36: 257-81.

Pollack, Mark A. 1997. Representing diffuse interests in EC policy-making. Journal of European Public Policy 4, no. 4: 572-90.

Salisbury, Robert H. 1979. Why No Corporatism in America? in Trends Towards Corporatist Intermediation. Editors Philippe C. Schmitter, and Gerhard Lehmbruch, 328. London and Beverly Hills: Sage Publications Ltd.

Scharpf, Fritz. 1999. Governing in Europe: Effective and Democratic? Oxford: Oxford University Press.

Schmitter, Philippe C. 2000. How to Democratize the European Union...and why bother? New York and Oxford: Rowman and Littelfield.

. 1979. Still the Century of Corporatism? in Trends Towards Corporatist Intermediation. Editors Philippe C. Schmitter, and Gerhard Lehmbruch, 7-52. London and Beverly Hills: Sage Publications Ltd.

. 2001. What is there to legitimize in the European Union...and how might this be accomplished? Paper Presented at the 29th ECPR Joint Sessions of Workshops. Workshop No. 5: "Governance and Democratic Legitimacy", Grenoble/France, 6-11 April 2001: 1-17. 
Schmitter, Philippe C., and Wolfgang Streeck. 1999. The Organization of Business Interests: Studying the Associative Action of Business in Advanced Industrial Societies. MaxPlanck-Institut Für Gesellschaftsforschung Discussion Paper 99/1.

Smismans, Stijn. 2000. The European Economic and Social Committee: towards deliberative democracy via a functional assembly. European Integration Online Papers 4, no. 12: 15.

- Forthcoming (a). Representation through interest committees: the case of the tripartite Advisory Committee for Safety, Hygiene and Health Protection at Work. in Les modes de représentation dans l'Union européenne. Editors Sabine Saurugger, and Bastien Irondelle. Paris: L'Harmattan.

- Forthcoming (b). European Civil Society: Shaped by discourses and institutional interests. European Law Journal, 9, no 4: 482-504.

Streeck, Wolfgang, and Philippe C. Schmitter. 1991. From national corporatism to transnational pluralism. Politics and Society 19, no. 2: 133-64.

Swanborn, P. G. 1993. Schaaltechnieken, Theorie en praktijk van acht eenvoudige procedures. Amsterdam: Boom.

Van Schendelen, M. C. P. M. 1994. National Public and Private EC Lobbying. AldershotBrookfield USA-Hong Kong-Singapore-Sydney: Dartmouth Publishing Company.

Wessels, Wolfgang. 1999. Comitology as a Research Subject: A New Legitimacy Mix? in EU Committees: Social Regulation, Law and Politics. Editors Christian Joerges, and Ellen Vos, 259-69. Oxford: Hart Publishing.

Zavvos, Georgios S. 1994. EC Financial Markets: Regulation for Stability and Openness. in Further Perspectives in Financial Integration in Europe. Editor Eddy Wymeersch, 27-42. Berlin and New York: Walter de Gruyter. 